\title{
Article
}

\section{Osteoporosis and prevention of fragility fractures}

\author{
Nuttall, Dilyse \\ Available at http://clok.uclan.ac.uk/24870/ \\ Nuttall, Dilyse ORCID: 0000-0002-0561-5229 (2018) Osteoporosis and \\ prevention of fragility fractures. Nurse Prescribing, 16 (11). pp. 532-533. ISSN \\ 2052-2924
}

It is advisable to refer to the publisher's version if you intend to cite from the work. 10.12968/npre.2018.16.11.532

For more information about UCLan's research in this area go to

http://www.uclan.ac.uk/researchgroups/ and search for < name of research Group $>$.

For information about Research generally at UCLan please go to http://www.uclan.ac.uk/research/

All outputs in CLoK are protected by Intellectual Property Rights law, including Copyright law. Copyright, IPR and Moral Rights for the works on this site are retained by the individual authors and/or other copyright owners. Terms and conditions for use of this material are defined in the policies page.

\section{CLoK}

Central Lancashire online Knowledge www.clok.uclan.ac.uk 


\section{Calculation Skills: Osteoporosis and prevention of fragility fractures}

The National Institute of Health (2014) explain osteoporosis as 'a disease in which the bones become weak and are more likely to break', suggesting the most vulnerable areas for the fractures to be the wrist, the spine and the hips. The increase risk of fracture in osteoporosis is a consequence of the low bone mass and the deterioration of the bone structure, (NICE 2016). The definition of osteoporosis is supported by criteria set by the World Health Organisation (WHO) (2007), stating that osteoporosis relates to a bone mineral density (BMD) of 2.5 standard deviations or more below the average value for young healthy women.

\section{Question 1}

Women are at greater risk of osteoporosis, with the risk increasing with age. NICE (2011) report that at by 80 years of age, the prevalence of osteoporosis is 25 times higher than at 50 years of age (when it is $2 \%$ ).

(i) What is the prevalence at 80 years?

(ii) Assuming that the prevalence increases at a consistent rate per year between the age of 50 and 80 years, what would the prevalence be at 69 years?

\section{Question 2}

A 2008 study, aiming to identify the incidence of fractures in England (Donaldson et al. 2008) estimated that the incidence was 3.6 fractures per 100 people per year. NICE (2016) suggest that 180,000 of the fractures in England and Wales each year are as a result of osteoporosis.

(i) Based on a population of 53 million in England, how many fractures occur annually in England?

(ii) Assuming the same incidence rate in Wales (with a population of 3 million), what percentage (rounded up or down to the nearest whole number) of fractures in England and Wales are likely to be as a result of osteoporosis?

\section{Question 3}

One of the risk factors associated with reduced bone mineral density (BMD) is a Body mass index* (BMI) of less than $18.5 \mathrm{~kg} / \mathrm{m}^{2}$ (NICE 2016). Which patient/s in table 1 are at increased risk of osteoporosis (based on BMI alone). Round your BMls up or down to two decimal points.

${ }^{*} \mathrm{BMI}=\mathrm{Kg} / \mathrm{M}^{2}$

\begin{tabular}{|l|l|l|}
\hline \multicolumn{2}{|l|}{ Table 1: Patient weight and height data for BMI } \\
\hline Patient & Weight $\mathbf{( k g )}$ & Height $\mathbf{( m )}$ \\
\hline Gillian & 39 & 1.4 \\
\hline Patricia & 53 & 1.7 \\
\hline Rosemary & 69 & 1.9 \\
\hline Alison & 49 & 1.6 \\
\hline
\end{tabular}




\section{Question 4}

Lucille was identified as being at high risk of fragility fracture following assessment of fragility risk and a dual-energy $x$-ray absorptiometry (DXA) scan. She is to commence bone-sparing treatment and because her calcium intake is inadequate, she will also be prescribed calcium and vitamin $D$ supplementation, with the following regime:

- alendronate $10 \mathrm{mg}$ once daily

- Colecalciferol 400 international units with calcium carbonate 1.5 grams daily

(i) Alendronate tablets are available in packs of $2810 \mathrm{mg}$ tablets, at a cost of $£ 3.25$. In order to treat Lucille throughout the whole of November 2018 and up to and including her next appointment on 27th January 2019, how many packs will need to be prescribed?

(ii) Colecalciferol 400 international units with calcium carbonate 1.5 gram tablets cost f3.65 for 56 tablets. What is the cost of 14 days treatment (rounded up or down to nearest pence)?

\section{Question 5}

NICE (2016) recommend that treatment with alendronate should continue for up to 10 years for patients whose fragility fracture risk remains high. A recent study by Leal et al (2016) suggested that the additional cost to the health service within the first year following treatment of a hip fracture was $f 10,860$ per patient. A GP appointment costs approximately $£ 36$ (Personal Social Services Research Unit 2016) and a DXA scan, approximately $f 120$.

A preventative plan can prove significantly more cost effective than treating a patient following a fracture. Calculate the difference in cost between that identified by Leal et al, for the first year following treatment of a hip fracture and the cost of the following seven year treatment plan for Lucille:

- two follow up appointments per year

- two repeat DXA scans within the 7 year period

- drug treatment regime as indicated in question 4

For the purpose of your calculations, assume all years have 365 days and base drug costs on the price of single tablets.

\section{Answers}

Question 1

(i) $25 \times 2 \%=50 \%$

(ii) Years between 50 and $80=30$

Difference in prevalence: $50-2=48$

Increase per year: $48 \div 30=1.6$

Years between 50 and $69=19$ 
Expected prevalence $=1.6 \times 19=30.4 \%$

Question 2

(i) 53 million $\div 100=530,000$

$530,000 \times 3.6=1,908,000$

(ii) Fracture in Wales $=3$ million $\div 100 \times 3.6=108,000$

Fractures in England and Wales $=1,908,000+108,000=2,016,000$

$1 \%$ of fractures $=2,016,000 \div 100=20160$

$180,000 \div 20160=9 \%$ (rounded up)

Question 3

Gillian: $\mathrm{BMI}=39 \div(1.4 \times 1.4)=19.90$

Patricia: $\mathrm{BMI}=53 \div(1.7 \times 1.7)=18.34$

Rosemary: $\mathrm{BMI}=69 \div(1.9 \times 1.9)=19.11$

Alison: $\mathrm{BMI}=49 \div(1.6 \times 1.6)=19.14$

Patricia is at increased risk based on BMI alone.

Question 4

(i) $\quad$ Days of treatment $=$ November 30 days December 31 days January 27 days Total $=88$

Packs required $=88 \div 28=3.14$ (so, 4 packs needed).

(ii) $\quad(£ 3.65 \div 56) \times 14=91 p$ (rounded down)

\section{Question 5}

7 years $=365 \times 7=2555$

Cost of treatment with alendronate: $(£ 3.25 \div 28) \times 2555=£ 296.56$

Cost of treatment with colecalciferol with calcium carbonate: $(3.65 \div 56) \times 2555=£ 166.53$

Cost of GP appointments: $£ 36 \times 14=£ 504$

Cost of DXA scans $=£ 120 \times 2=£ 240$

Total cost of treatment plan $=£ 296.56+£ 166.53+£ 504+£ 240=£ 1207.09$

Saving $=£ 10,860-£ 1207.09=£ 9652.91$ 


\section{References}

Donaldson, L., Reckless, I., Scholes, S., et al. (2008). The epidemiology of fractures in England. Journal of epidemiology and community health. 62. 174-80.

Leal, J., Gray, A. M., Prieto-Alhambra, D., Arden, N. K., Cooper, C., Javaid, M. K., The REFReSH study group. (2016). Impact of hip fracture on hospital care costs: a population-based study.

Osteoporosis International, 27, 549-558.

National Institute for Health and Care Excellence (NICE) (2016) Osteoporosis - prevention of fragility fractures, Clinical knowledge summaries (online). Available at: https://cks.nice.org.uk/osteoporosisprevention-of-fragility-fractures\#! backgroundsub

NICE (2011) Alendronate, etidronate, risedronate, raloxifene, strontium ranelate and teriparatide for the secondary prevention of osteoporotic fragility fractures in postmenopausal women (amended) (NICE technology appraisal 161 (amended)) (online). Available at:

https://www.nice.org.uk/guidance/TA161

National Institute of Health (2014) What is osteoporosis? Fast Facts: An Easy-to-Read Series of Publications for the Public (online). Available at: https://www.bones.nih.gov/healthinfo/bone/osteoporosis/osteoporosis-ff

Personal Social Services Research Unit (2016) Unit Costs of Health \& Social Care 2016 (online). Available at: https://www.pssru.ac.uk/pub/uc/uc2016/full.pdf?uc=2016-full

World Health Organisation (2007) WHO Scientific group on the assessment of osteoporosis at primary health care level. Geneva: WHO 